\title{
Ripples, under-currents and tsunamis
}

Stephen Hancocks OBE

Editor-in-Chief

The BDJ Upfront section includes editorials, letters, news, book reviews and interviews. Please direct your correspondence to the News Editor,

Kate Quinlan at k.quinlan@nature.com. Press releases or articles may be edited, and should include a colour photograph if possible.

W e use descriptions of movements of water to express many of our feelings, imbuing them with romantic emotional values that are absent from the mere physical motions. The pandemic has not been immune from this process and as this year has progressed we have been seeing the emergence of more and more examples.

The basis of these comparisons in relation to COVID-19 were the initially unseen and unimagined consequences of the viral infection itself, a silent whirlpool of uncertainty. But as the year has progressed these consequences and the corresponding adjectives have widened due to lockdowns, quarantines and restrictions that have variously been placed on us all. In whatever walk of life we operate the changes in society, voluntary and imposed, have had profound effects. For us in dentistry the disruption in the delivery of oral care has been lifechanging. These dislocations are not limited to the professional conduct of examination, diagnosis and treatment of patients, but encompass business practices, profitability, employment, contracts, indeed all aspects of our livelihoods.

Each of these adaptations have ripple effects. The pandemic has made us aware of how connected we all are, personally, locally, nationally and internationally in a way that few previously comprehended. So that a pebble dropped in a pool quickly, smoothly and deceivingly poetically, causes ripples that extend way beyond the realm of the person who released it. This month's issue of $B D J$ In Practice carries an excellent example in its cover story by David Westgarth of the pandemic-induced plight of dental laboratories and technicians. The massive fall-off of dental procedures needing laboratory work and the way in which that part of the profession is funded has left it all but bereft. What happens as and when we resume? Will there be anyone left to make dentures and crowns?

Many examples can be conjured from a myriad of other occupations: hairdressers, café owners, retailers, gardeners, the list is sometimes surprising but always humbling. Intertwined with these, however, are longerterm health consequences. November sees the annual Mouth Cancer Awareness Month which this year is more pertinent than ever since the levels of referral and diagnosis are at historic lows. Aside from the direct effects of COVID-19 what are the added morbidity and mortality costs of this condition alone?

At the beginning of the pandemic the understandable human fear of the unknown meant that sensible, defensive, emergency measures were entirely appropriate. Within even this short period of time better

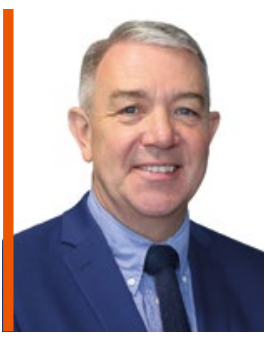

\section{'Should we shrug at the ripples or support the under-currents and to what extent?'}

understanding of the coronavirus, detection, prevention and even treatment have developed. In some ways life has returned to a semblance of normal. Yet now there is a growing sense of under-currents, those strong swirlings that disturb the surface in an albeit subtler if more disturbing way. Education is a clear imperative and nowhere more so than in dentistry where human contact is the centrality of the activity. We know the negative effects that young people are experiencing from senior school age upwards as their learning, exams and future prospects are all subject to the unknown, to stress and to their mental wellbeing. What is the price of future health and healthcare when tallied against illness and death mediated by the virus? It is a near-impossible calculation but one for which we have to try and find an algorithm, with increasing urgency, with or without the advent of a vaccine.

Apart from 'unprecedented' the most used word since March has been 'evidence' and one of the hottest debates has been about how such evidence is interpreted and used politically. It may have escaped my attention elsewhere but certainly we have not received any research that shows any evidence of how dental team members, or patients, in any country in the world have contracted COVID-19 infections through providing and receiving dental care. Does this indicate that we are getting it about right? Does this remind us of a similar point on the journey with HIV?

So where do these strands leave us just now? Should we shrug at the ripples or support the 